\title{
Perubahan Sosio-Kultur Madrasah Aliyah Miftahul Ulum Lumajang dan Masa Depan Madrasah Pasca Berakhirnya Pandemi Covid-19 Perspektif Teori Social Engineering
}

\author{
Zainuddin, M.Pd. \\ MA Miftahul Ulum Banyuputih Kidul Jatiroto Lumajang
}

Keywords:
Sosio-Kultur, Madrasah, Pandemi
Covid-19, Teori Social Engineering

*Correspondence Address: mughnillubib@gmail.com

\begin{abstract}
The Indonesian government's efforts to suppress the spread of Covid-19 directly impact the socio-cultural changes of madrasas, the phenomenon of culture shock occurring at all levels of education. This study seeks to describe and analyze the dynamics of socio-cultural changes at MA Miftahul Ulum Lumajang after the COVID-19 pandemic using social engineering theory as an analytical tool. The research method uses a phenomenological qualitative approach. The results showed: The socio-cultural changes that occurred in MA Miftahul Ulum Banyuputih Kidul Jatiroto Lumajang during the covid-19 pandemic covered various aspects, both in terms of teaching and learning activities, communication patterns between teachers and students, including the psychological aspects of teachers and students in dealing with learning activities. Teaching (KBM) to create a new paradigm for teachers and students viewing KBM that cannot be limited by space and time.
\end{abstract}

Abstrak: Upaya pemerintah Indonesia dalam menekan laju penyebaran Covid-19 secara langsung berdampak pada perubahan sosio-kultur madrasah secara signifikan, fenomena shock cultur terjadi di segala tingkatan pendidikan. Penelitian ini berupaya mendeskripsikan dan menganalisis dinamika perubahan sosio-kultur yang terjadi di MA Miftahul Ulum Lumajang pasca pandemi covid-19 menggunakan teori social engineering sebagai pisau analisis. Metode penelitian menggunakan pendekatan kualitatif fenomenologis. Hasil penelitian menunjukkan: Perubahan sosio-kultur yang terjadi di MA Miftahul Ulum Banyuputih Kidul Jatiroto Lumajang selama pandemi covid-19 mencakup berbagai aspek, baik segi kegiatan belajar mengajar, pola komunikasi antara guru dan siswa, termasuk aspek psikis guru dan siswa dalam menghadapi kegiatan belajar mengajar (KBM) sehingga tercipta paradigma baru bagi guru dan siswa dalam melihat KBM yang tidak bisa dibatasi ruang dan waktu.

\section{PENDAHULUAN}

Pandemi Covid-19 yang melanda Indonesia mengakibatkan dampak sistemik ke berbagai bidang kehidupan termasuk pendidikan. Untuk menekan laju penyebaran Covid-19 pemerintah melalui Kemendikbud mengeluarkan kebijakan bahwa kegiatan belajar mengajar dilakukan dari jarak jauh. ${ }^{1}$ Implikasi paling nyata dari model pembelajaran secara daring adalah berkurangnya interaksi atara guru dan

1"Surat Edaran Sekretaris Jenderal Kementrian Pendidikan Dan Kebudayaan Nomor 15 Tahun 2020," 2020, 2-3. 
siswa atau bahkan antar siswa sendiri. Minimnya interaksi ini tentu menjadi penghambat tersendiri atas terwujudnya hasil belajar dalam proses belajar mengajar. Guru dan siswa mendapat pengalaman baru dalam proses belajar mengajar selama pandemii ini. ${ }^{2}$

Perubahan ini menimbulkan pro dan kontra, yang paling jelas adalah, adanya kebijakan Pembelajaran Jarak Jauh (PJJ) memperlihatkan bahwa infrastruktur teknologi di Negara ini belum merata. Di MA Miftahul Ulum Lumajang ada sebagian siswa yang kebetulan rumahnya di pedesaan merasa kesulitan mengikuti sekolah secara daring, karena kendala saluran telekomunikasi di pedesaan yang masih belum sebaik di perkotaan. Ini adalah salah satu gambaran kendala yang harus dihadapi dan dicarikan solusinya.

Sebagaimana dikutib Dzaljad, Anthony Giddens menyatakan "runway world" dampak globalisasi dan disrupsi teknologi telah mengubah wajah dunia dengan sangat cepat. Dunia mengalami perubahan begitu massif, tidak beraturan, serta sulit ditebak fase akhirnya. Saat ini dunia sedang dalam keadaan panik dan terus berubah yang akibatnya muncul berbagai kekacauan dan krisis akibat dari terjadinya pandemi covid-19. ${ }^{3}$

Keadan ini dapat dikatakan menjadi tantangan besar dunia pendidikan dalam rangka menyiapkan siswa melalui kegiatan belajar mengajar bagi peranannya di masa mendatang. "Pembelajaran berdasarkan makna leksikal berarti

${ }^{2}$ Ayusi Perdana Putri et al., "Strategi Pembelajaran Melalui Daring Dan Luring Selama Pandemi Covid-19 Di SD Negeri Sugihan 03 Bendosari," Prima Magistra: Jurnal Ilmiah Kependidikan 2, no. 1 (2021): 8.

${ }^{3}$ Rifma Ghulam Dzaljad, "Transformasi Sosial Dalam Proses Pendidikan Di Masa Pandemi Covid-19," Maarif Institute 15, no. 2 (2020),306. proses, cara, perbuatan mempelajari". Keberhasilan pencapaian siswa tidak bergantung pada proses pembelajaran, namun juga bergantung pada siswa itu sendiri. Karena hasil yang baik itu dipengaruhi oleh berbagai komponen, dan terutama bagaimana aktivitas belajar siswa sebagai subjek belajar. ${ }^{4}$

Artikel ini akan mendeskripsikan dan menganalisis perubahan sosiokultur MA Miftahul Ulum Lumajang pasca terjadinya pandemi covid-19. Hal ini peneliti lakukan karena banyak sekali perubahan yang terjadi pasca kebijakan PJJ, yang sudah barang tentu memberi efek domino terhadap sosiokultur sekolah. Peneliti akan menganalisis perubahan sosio-kultur madrasah menggunakan teori Sosial Engineering, alasannya adalah untuk memetakan perubahan yang terjadi kemudian meraba konsep pembelajaran masa depan di MA Miftahul Ulum Lumajang ketika kegiatan belajar mengajar kembali normal seperti sedia kala.

Secara sosio-kultur semenjak penerapan kebijakan PJJ ada perubahan pola belajar siswa di MA Miftahul Ulum Lumajang. Dengan mengikuti pembelajaran dari rumah, praktis pola relasi dan komunikasi dengan guru dan teman sebaya berubah. Intensitasnya mungkin masih sama, tapi tidak dengan kualitasnya. Hal ini menjadi semacam shock culture bagi siswa MA Miftahul Ulum Lumajang. Minimal untuk saat ini, dimana mereka masih belum terbiasa dengan adanya pembelajaran secara daring.

\footnotetext{
${ }^{4}$ Wayan Tirka and Ni Made Kusumawati, "Optimalisasi Model Pembelajaran Berbasis Masalah Dengan Berbantuan Lembar Kerja Siswa (Lks) Untuk Meningkatkan Aktivitas Dan Hasil Belajar Dalam Mata Pelajaran Matematika," International Journal of Elementary Education 1, no. 3 (2017), 197.
} 
Adanya pandemi covid-19 memang menimbulkan kecemasan, termasuk dalam ranah pendidikan. Namun daripada terus cemas dan meratapi perubahan mendadak di sekolah karena efek pandemi, peneliti melihat ada beberapa kreasi dan inovasi yang dapat dijadikan patokan untuk membangun madrasah yang lebih baik di masa depan, ketika covid19 sudah dapat ditangani dan KBM kembali seperti semula, seperti penggunaan media elektronik maupun online dalam pembelajaran yang begitu massif selama PJJ berlangsung, termasuk komunikasi sekolah dengan wali murid yang lebih intens melalui media sosial sekolah dan website sekolah. Secara sederhana gambaran madrasah berbasis teknologi dan multimedia dapat mulai terlihat akibat pandemi ini.

Model pembelajaran daring selama pandemi ini pada akhirnya menuntut guru untuk tidak hanya mampu merumuskan strategi pembelajaran namun juga mampu melakukan penetrasi sosial ke para orang tua siswa.

Mempertimbangkan konteks terkini guru juga perlu memiliki kompetensi sosial guna mendukung efektivfitas kegiatan belajar mengajar. Kemampuan ini sangat menunjang hubungan sekolah dan masyarakat supaya semakin harmonis, dan sinergi antara sekolah dan masyarakat dapat berjalan dengan baik. Kompetensi social perlu digalakkan berkelindan dengan kemampuan guru dalam berkomunikasi, berkerjasama, bergaul, dan memiliki kepribadian yang

${ }^{5}$ Imron Fauzi, Etika Profesi Keguruan, IAIN Jember Press, II (Jember: IAIN Jember Press, 2019).

${ }^{6}$ Roy Schwartzman, "Performing Pandemic Pedagogy," Communication Education, 69 (4), (2020), 515. menyenangkan. Dengan demikian, inti dari kompetensi social terletak pada komunikasi yang efektif. Komunikasi juga merupakan keseluruhan dari pada perasaan, sikap, dan harapan-harapan yang disampaikan baik secara langsung atau tidak langsung, baik yang dilakukan secara sadar atau tidak sadar karena komunikasi merupakan bagian integral dari proses perubahan. ${ }^{5}$

Pandemi COVID-19 merangsang kekhawatiran mendasar, pandemi memaksa konfrontasi dengan kerentanan sambil mendorong perluasan kemampuan. Disiplin komunikasi memiliki peran yang sangat penting untuk dimainkan dalam menciptakan dunia pasca pandemi yang dapat mendorong ketahanan sekaligus memperkuat dan memperluas lingkup saling peduli. Penelitian-penelitian lanjutan perlu digalakkan untuk menyelidiki desain pendidikan yang dipersiapkan oleh pendidikan pasca pandemi. ${ }^{6}$

\section{LANDASAN TEORI}

\section{Penelitian Terdahulu}

Penelitian

terdahulu dicantumkan guna memetakan penelitian yang telah dilakukan oleh para peneliti sebelumnya, ini dilakukan guna menghindari adanya tumpang tindih atas bidang kajian yang sama. Adapun penelitian terdahulu yang peneliti gunakan sebagai pertimbangan adalah:

Rizqon Halal Syah Aji, berjudul: Dampak Covid-19 pada Pendidikan di Indonesia: Sekolah, Keterampilan, dan Proses Pembelajaran. ${ }^{7}$ Hasil penelitian menunjukkan: Kebijakan pembelajaran

\footnotetext{
${ }^{7}$ Rizqon Halal Syah Aji, "Dampak Covid-19 Pada Pendidikan Di Indonesia: Sekolah, Keterampilan, Dan Proses Pembelajaran," SALAM: Jurnal Sosial Dan Budaya Syar-i, 7 (5), (2020).
} 
jarak jauh telah menyebabkan kendala besar, baik dalam aspek proses pembelajarannya, penilaiannya, peluang mendapatkan pekerjaan setelah lulus, serta pembatalan penilaian publik dalam rangka seleksi pekerjaan. Pemulihan situasi dan kondisi ini harus dilakukan secara cepat dan tepat, tentu dengan sokongan anggaran pemerintah untuk pendidikan. Pemangkasan birokrasi pendidikan harus segera dilakukan dalam menghadapi situasi darurat akibat pandemi covid-19 bagi dunia pendidikan. Salah satu yang paling urgen untuk dilakukan adalah mendesain ulang sistem penilaian dalam pembelajara, alih-alih menghilangkan sebagaimana sempat diwacanakan sebagai alter solusi selama pandemi, sehingga keijakan paling tepat guna adalah menunda penilaia bukan melewatkan penilaian internal sekolah.

Hamidi, berjudul: Strategi Lembaga Pendidikan Islam dalam Menghadapi Era New Normal Pasca Pandemi Covid-19.8 Hasil penelitian menunjukkan bahwa: Strategi lembaga pendidikan Islam dalam menghadapi pandemi covid-19 adalah melakukan penataan ulang terhadap tata kelola sekolah. Lembaga pendidikan islam harus responsive terhadap perkembangan dan perubahan tata kelola pendidikan yang ada, karena bagaimanapun Lembaga pendidikan islam besar perananya dalam mengasah dan melahirkan sikap kesadaran, kedisiplinan dalam tata kelola kelembagaan. Pihak lembaga harus bias menjamin kesehatan para pendidik dan peserta didik selama penerapan pembelajaran blended

${ }^{8}$ Hamidi, "Strategi Lembaga Pendidikan Islam Dalam Menghadapi Era New Normal Pasca Pendemi Covid-19," Al-Fikrah, 2 (2), (2020). learning. Ini merupakan bukti konkret keseriusan lembaga pendidikan islam dalam menjaga keberlangsungan proses pembelajaran. Mempersiapkan sumber daya manusia yang mumpuni merupakan aspek yang urgen dalam penerapan blended learning. Oleh sebab itu pengembangan sumber daya manusia di lembaga pendidikan islam merupakan sebuah keniscayaan untuk dilaksanakan secara berkala.

Amy Maguire and Donna McNamara, berjudul: Human Rights and The Post-Pandemic Return to Classroom Education in Australia. ${ }^{9}$ Hasil penelitian menunjukkan: Pandemi Covid-19 adalah krisis yang berdampak ke berbagai bidang seperti sektor pendidikan, ekonomi, dan sosial. Berdasarkan analisis hak asasi manusia, pandemi pertama dan terutama merupakan krisis kesehatan yang menimbulkan risiko signifikan terhadap hak untuk hidup. Berdasar fakta ini kembali ke pembelajaran berbasis kelas menimbulkan pertanyaan hukum dan etika yang kompleks tentang bagaimana masyarakat dapat mencapai keseimbangan proporsional antara hak-hak dalam krisis seperti ini. Artikel ini menggunakan kerangka hak asasi manusia untuk menyoroti beberapa ketegangan yang muncul di antara hak atas kesehatan, pendidikan dan pekerjaan dalam konteks kembali ke sekolah di masa pandemi. Pembuat kebijakan dan masyarakat luas ditantang untuk membuat pilihan saat ini antara kehilangan nyawa manusia atau melakukan lockdown yang tentu berimbas pada ranah pendidikan. Upaya penyeimbangan ini merupakan kewajiban masyarakat Australia, yang

${ }^{9}$ Amy Maguire and Donna McNamara, "Human Rights and the Post-Pandemic Return to Classroom Education in Australia," Alternative Law Journal, 45 (3), (2020). 
memiliki kapasitas untuk membuat pilihan yang berdampak positif bagi realisasi hak asasi setiap orang, termasuk anggota masyarakat yang paling rentan terpapar covid-19.

\section{Perubahan Sosial dan Pendidikan}

Menurut Sztompka sebagaimana dikutip Indraddin dan Irwan perubahan sosial sangat berhubungan dengan perubahan struktur, dimana perubahan struktur lebih mengarah kepada perubahan sistem. Hal tersebut berorientasi bahwa jika struktur berubah akan mengakibatkan semua unsur dalam masyarakat akan berubah. Sejalan dengan itu, Soekanto berpendapat bahwa suatu kondisi sosial primer yang berubah dalam masyarakat akan mengakibatkan perubahan terhadap yang lain. Misalnya, terjadinya perubahan ekonomi, politik, geografis, yang menyangkut perubahan aspek kehidupan lainnya. ${ }^{10}$

Perubahan terjadi karena adanya ketidaksesuaian yang mengakibatkan ketidakserasian di dalam masyarakat. Keadaan yang terjadi memaksa masyarakat untuk merubah kebiasaan yang ada dalam kehidupan sehari-hari. Teknologi dianggap untuk saat ini sebagai pengganti posisi guru-dosen dalam pembelajaran. Hal ini tidak semuanya benar, peran guru-dosen dalam melakukan pembelajaran masih sangat diperlukan (proses manusiawi, dan kurang tepat bahwa

${ }^{10}$ Indraddin and Irwan, Strategi Dan Perubahan Sosial, Sosiologi, 1st ed. (Yogyakarta: Deepublish, 2016), 36.

${ }^{11}$ Nur Khairiyah Mar'ah, Ani. Rusilowati, and Woro Sumarni, "Perubahan Proses Pembelajaran Daring Pada Siswa Sekolah Dasar," Prosiding Seminar Nasional Pascasarjana UNNES, (2020), 1. teknologi selalu melahirkan proses dehumanisasi). ${ }^{11}$

Perubahan kurikulum dan perubahan budaya, keduanya saling bertautan satu dengan yang lain dan berdampak luas di masyarakat. Adanya perubahan kurikulum pendidikan dapat mempengaruhi perubahan budaya pada masyarakat. Perubahan inilah nantinya akan memunyai fungsi reproduksi budaya, yaitu mengembangan dan menganalisis budaya, kemudian melakukan modifikasi dan pembaruan yang lebih mendasar (Achruh, 2018). Sebaliknya, perubahan budaya dapat mempengaruhi perubahan cara pikir dan interaksi seseorang. ${ }^{12}$

Perubahan kurikulum karena perubahan budaya dapat kita saksikan secara langsung saat ini. Dimana budaya pembelajaran di sekolah selama ini adalah dengan tatap muka langsung/ luar jaringan (luring). Namun dengan adanya pandemic covid-19, budaya pembelajaran secara mendadak mengalami perubahan menjadi pembelajaran online/ dalam jaringan (daring). Perubahan budaya ini tentu saja memunculkan kendalakendala baru baik dari pihak guru, siswa maupun orang tua. Kendala bagi guru adalah kurangnya penguasaan pada aplikasi pembelajaran, pengelolaan pembelajaran, penilaian, dan pengawasan secara online sehingga dalam pengajarannya guru mengandalkan metode penugasan. ${ }^{13}$

\footnotetext{
${ }^{12}$ Annisa Mega et al., "Perubahan Kurikulum
} Yang Didasari Oleh Perubahan Sosial Dan Budaya Di Masyarakat," Seminar Nasional Jurusan Administrasi Pendidikan FIP Universitas Negeri Malang, (2020), 9.

${ }^{13}$ Henry Aditia Rigianti, "Kendala Pembelajaran Daring Guru Sekolah Dasar di 


\section{Social Engineering}

Suatu perubahan sosial yang dikehendaki atau direncanakan, selalu berada di bawah pengendalian serta pengawasan pelopor perubahan tersebut. Cara untuk mempengaruhi masyarakat dengan sistem yang teratur dan direncanakan terlebih dahulu, dinamakan social engineering atau social planning. Hukum mepunyai pengaruh langsung atau pengaruh yang tidak langsung di dalam mendorong terjadinya perubahan sosial. Misalnya, suatu peraturan yang menentukan sistem pendidikan tertentu bagi warga Negara mepunyai pengaruh secara tidak langsung yang sangat penting bagi terjadinya perubahan sosial. ${ }^{14}$

Rekayasa sosial tidak akan berhasil tanpa diawali oleh adanya perubahan cara berpikir. Rekayasa sosial, secara sederhana, dapat dimaknai sebagai tindakan untuk mempengaruhi sikap dan tindakan sosial dalam skala besar. Istilah "rekayasa sosial" lahir di Uni Soviet pada tahun 1920-an, untuk menggulingkan kekuasaan Tsar Rusia. Pemerintah Uni Soviet menggunakan koran, buku, film, dan bahan arsitektur untuk mengubah tatanan dan struktur ideologi masyarakat. ${ }^{15}$

Rekayasa sosial merupakan sebuah jalan untuk melakukan sebuah perubahan sosial secara terencana. Konsep rekayasa sosial

Kabupaten Banjarnegara," Elementary School, 2 (1), (2020), 229.

${ }^{14}$ Fithriatus Shalihah, Sosiologi Hukum, 1st ed. (Depok: PT RajaGrafindo Persada Jakarta, 2017), 88.

${ }^{15}$ Nurul Zuriah and Hari Sunaryo, "Rekayasa Sosial Model Pendidikan Karakter Berbasis Nilai Kearifan Lokal Dan Civic Virtue Di Perguruan Tinggi," Sosiohumanika: Jurnal Pendidikan Sains Sosial Dan Kemanusiaan, 11 (2), (2018), 162. pada dasarnya berupa planned social change (perubahan sosial yang terencana). Sebuah rekayasa sosial berkaitan dengan upaya untuk mewujudkan visi, misi dan tujuan tertentu. Proses ke arah perubahan sosial harus diawali dengan ide tentang ketiga hal tersebut. ${ }^{16}$

\section{Sosiologi Pendidikan}

Sekolah merupakan salah satu institusi sosial yang mempengaruhi dan mewariskan proses sosialbudaya masyarakat kepada anak. Sekolah merupakan suatu sistem sosial yang mempunyai organisasi dan pola relasi sosial diantara para anggotanya yang bersifat unik. Ini disebut sebagai kebudayaan sekolah. Sekolah mengajarkan hal-hal yang belum dipelajari dalam keluarga dan kelompok bermain. Pendidikan formal mempersiapkan diri seseorang untuk menguasai peranan-peranan baru dikemudian hari, saat seseorang tidak lagi menggantungkan diri pada orang tuanya. ${ }^{17}$

Sekolah sebagai lembaga penyelenggara pendidikan harus bersiaga memfasilitasi perubahan apapun menyangkut pendidikan siswanya. Pendidikan tingkah laku harus menjadi pijakan kuat ditengah perkembangan teknologi dan arus percepatan informasi. Programprogram pendidikan yang dilakukan sekolah harus benar-benar disampaikan kepada murid, terlebih

${ }^{16}$ Taat Wulandari, "Rekayasa Sosial Kolaborasi Pendidikan Karakter Dan Pendidikan Multikultural: Praksis Di Yayasan Perguruan Sultan Iskandar Muda," Jurnal Pembangunan Pendidikan: Fondasi Dan Aplikasi, 4 (2), (2017), 189.

${ }^{17}$ Zaitun, Sosiologi Pendidikan: Analisis Komprehensif Aspek Pendidikan Dan Proses Sosial, Sosiologi Pendidikan, 1st ed. (Pekanbaru: Kreasi Edukasi, 2015), 19. 
dengan media daring tetap saja pihak sekolah harus benar-benar memperhatikan etika sebagai lembaga pendidikan. Penekanan belajar dirumah kepada murid harus benar-benar mendapat kawalan agar guru-guru yang mengajar melalui media garing tetap smooth dan cerdas dalam menyampaikan pelajaran-pelajaran yang wajib dipahami oleh murid. ${ }^{18}$

\section{METODE}

\section{Fokus Penelitian}

Fokus penelitian ini akan menganalisis dinamika perubahan sosio-kultur yang terjadi di MA Miftahul Ulum Lumajang pasca pandemi covid-19 menggunakan teori social engineering sebagai pisau analisa.

\section{Jenis dan Pendekatan Penelitian}

Penelitian ini tergolong penelitian lapangan dengan peneliti terlibat langsung ke lokasi penelitian guna melihat secara konkret mengenai kondisi dan situasi setempat.19 Pendekatan penelitian menggunakan pendekatan kualitatif fenomenologis, dengan menyajikan data berupa hasil interview dan dokumen, sehingga bisa menggambarkan realitas dibalik fenomena yang terjadi di lapangan secara lebih dalam, rinci dan tuntas. ${ }^{20}$

\section{Lokasi Penelitian}

Penelitian ini dilaksanakan di MA Miftahul Ulum Lumajang. Alasan lokasi ini dipilih karena MA Miftahul Ulum merupakan madrasah yang

\footnotetext{
${ }^{18}$ Aji, "Dampak Covid-19 Pada Pendidikan Di Indonesia: Sekolah, Keterampilan, Dan Proses Pembelajaran", SALAM: Jurnal Sosial \& Budaya Syar'i, 7 (5), (2020), 400.

${ }^{19}$ A.M. Susilo Pradoko, Paradigma Metode Penelitian Kualitatif, Yogyakarta: UNY Press (Yogyakarta: UNY Press, 2017), 178.
}

berbasis di pesantren yang menerapkan kegiatan pembejalaran daring dan luring secara bersamaan selama pandemi.

\section{Metode Penentuan Sampel}

Secara praktis fokus penelitian dibatasi hanya pada fenomena perubahan sosio-kultur MA Miftahul Ulum Lumajang pasca pandemi covid-19. Penelitian ini teknik menggunakan teknik purposive sampling dalam penentuan sampel, yaitu teknik pengambilan sampel sumber data dengan pertimbangan tertentu. ${ }^{21}$ Alasan menggunakan teknik ini adalah karena tidak semua sampel memiliki kriteria yang sesuai dengan fokus penelitian mengenai sosio-kultur MA Miftahul Ulum Lumajang pasca pandemi covid-19 perspektif teori social engineering. Kriteria yang menjadi parameter dalam penentuan sampel dalam penelitian ini adalah stakeholder sekolah yang melaksanakan pembelajaran jarak jauh selama pandemi, meliputi: kepala sekolah, pejabat struktural sekolah, guru, dan siswa.

5. Metode Pengumpulan dan Pengecekan Keabsahan Data

Adapun metode pengumpulan data yang peneliti gunakan adalah wawancara dan dokumentasi. Dengan tahapan analisis data meliputi tahapan pengeditan, klasifikasi data, verifikasi, dan terakhir analisis hasil penelitian.

Adapun metode pengecekan keabsahan data peneliti

\footnotetext{
${ }^{20}$ Lexy J. Moleong, Metodologi Penelitian Kualitatif, (Bandung: Remaja Rosdakarya, 2010), 131.

${ }^{21}$ Sugiyono, Metode Penelitian Kuantitatif Kualitatif dan R\&D, (Bandung: Alfabeta, 2010), 85.
} 
menggunakan: Triangulasi sumber data dan triangulasi metode. ${ }^{22}$

\section{HASIL DAN DISKUSI}

Perubahan sosio-kultur sekolah selama pandemi setidaknya memunculkan tiga tantangan: 1) Tantangan Situasional dan Lingkungan, siswa melaporkan tantangan terbesar mereka untuk berkonsentrasi saat berada di rumah. Ada banyak pengecoh seperti anggota keluarga, kebisingan, dan pekerjaan rumah. Juga, siswa mengasosiasikan rumah dengan ruang untuk relaksasi, sehingga konsentrasi menjadi sulit. 2) Tantangan Pendidikan Online, tantangan utama yang dilaporkan adalah lingkungan online. Siswa melaporkan, "Ini sangat sulit," dan "Menatap layar membuat saya lelah". Kelelahan dalam mengikuti pembelajaran secara daring ini juga berkelindang dengan tantangan ketiga yakni 3) Tantangan Emosional, peserta melaporkan kurangnya motivasi dan emosi negatif sebagai tantangan emosional yang paling umum. Siswa menyebutkan,"Perintah tinggal di rumah telah membuat saya kehilangan banyak motivasi," dan "menemukan motivasi untuk terlibat ketika Anda bahkan belum bangun dari tempat tidur." Mengenai tantangan emosional, siswa melaporkan stres, kecemasan, khawatir sakit (virus corona), dan perubahan kesehatan mental mereka. ${ }^{23}$

Di MA Miftahul Ulum Banyuputih Kidul Jatiroto Lumajang perubahan sosio-kultur yang paling kentara tentu perubahan KBM dari tatap muka menjadi pembelajaran jarak jauh, secara sosiologis perubahan ini memiliki dampak sistemik terhadap

\footnotetext{
${ }^{22}$ Moleong, "Metodologi Penelitian Kualitatif."

${ }^{23}$ A. Patricia Aguilera-Hermida, "College Students' Use and Acceptance of Emergency Online Learning Due to COVID-19,"
}

perubahan pola komunikasi guru dan siswa, guru dan orang tua siswa, dan siswa dengan orang tuanya. Secara kosmik sekolah tidak lagi terikat dengan ruang kelas, melalui PJJ siswa bisa mengakses e-learning yang digunakan sekolah dari mana saja. Pembelajaran secara daring tentu sangat bergantung terhadap akses perangkat elektronik dan digital yang sangat signifikan. Pemenuhan aspek struktur penunjang PJJ ini menjadi sesuatu yang urgen bagi MA Miftahul Ulum selama pandemi ini.

Data Kementerian Koordinator Pembangunan Manusia dan Kebudayaan bahwa terdapat 46 ribu sekolah yang tidak memiliki akses internet, tidak dimilikinya perangkat elektronik oleh siswa serta adanya potensi siswa putus sekolah dan terpaksa bekerja akan meningkat tajam melebihi angka putus sekolah sebesar 4,5 juta di tahun 2019.24

Proses pembelajaran dikatakan berhasil dan berkualitas apabila seluruh siswa terlibat secara aktif, baik mental, fisik maupun sosial dalam proses pembelajaran. Selain itu siswa menunjukkan kegairahan belajar yang tinggi, semangat belajar yang besar, dan rasa percaya pada diri sendiri. Sedangkan dari segi hasil, proses pembelajaran dikatakan berhasil apabila terjadi perubahan perilaku yang positif pada diri siswa seluruhnya. Proses pembelajaran dikatakan berhasil dan berkualitas apabila masukan merata menghasilkan output yang banyak dan bermutu tinggi, serta sesuai dengan kebutuhan,

\footnotetext{
International Journal of Educational Research Open, 1 (1), (September, 2020), 5.

${ }^{24}$ Dzaljad, Transformasi Sosial Dalam Proses Pendidikan Di Masa Pandemi Covid-19, 309.
} 
perkembangan masyarakat dan pembangunan. ${ }^{25}$

Aneka perubahan yang terjadi di MA Miftahul Ulum selama pandemi, tentu juga merubah sudut pandang seluruh stekholder madrasah. Ada perubahan paradigma dalam cara pendidik memberikan pendidikan berkualitas-melalui berbagai platform online. Pembelajaran online, pendidikan jarak jauh, dan pendidikan berkelanjutan telah menjadi solusi untuk pandemi global yang belum pernah terjadi sebelumnya ini, terlepas dari tantangan yang dihadapi baik oleh pendidik maupun peserta didik. Transisi dari pembelajaran tatap muka tradisional ke pembelajaran online dapat menjadi pengalaman yang sama sekali berbeda bagi pelajar dan pendidik, yang harus mereka sesuaikan dengan sedikit atau tanpa alternatif lain yang tersedia. Sistem pendidikan dan para pendidik telah mengadopsi "Pendidikan dalam Keadaan Darurat" melalui berbagai platform online dan dipaksa untuk mengadopsi sistem yang tidak mereka persiapkan. ${ }^{26}$

$\begin{array}{ccr}\text { Salah } & \text { satu penelitian } \\ \text { menunjukkan bahwa penggunaan }\end{array}$ internet dan teknologi multimedia mampu merombak cara penyampaian pengetahuan dan dapat menjadi alternatif pembelajaran yang dilaksanakan dalam kelas tradisional. Pembelajaran daring adalah pembelajaran yang mampu mempertemukan mahasiswa dan dosen untuk melaksanakan interaksi pembelajaran dengan bantuan internet. Pada tataran pelaksanaanya

\footnotetext{
${ }^{25}$ Dewi Umi Kulsum, “Optimalisasi Penggunaan Buku Teks Dalam Upaya Meningkatkan Prestasi Belajar Di SMP," Jurnal Manajemen Pendidikan, 10 (1), (2015), 112.

${ }^{26}$ Sumitra Pokhrel and Roshan Chhetri, "A Literature Review on Impact of COVID-19 Pandemic on Teaching and Learning," Higher Education for the Future, 8 (1), (2021), 134.
}

pembelajaran daring memerlukan dukungan perangkat-perangkat mobile seperti smartphone atau telepon adroid, laptop, komputer, tablet, dan iphone yang dapat dipergunakan untuk mengakses informasi kapan saja dan dimana saja. Pembelajaran secara daring telah menjadi tuntutan dunia pendidikan sejak beberapa tahun terakhir. Pembelajaran daring dibutuhkan dalam pembelajaran di era revolusi industri 4.0.27

Mengutip tulisan Hamidi, menurut Chaeruman dan Mudiarti, secara teoritis blended learning memiliki empat pola berbeda: ${ }^{28}$

1. Singkron Langsung (live synchronous), yakni pembelajaran yang dilakukan secara tatap muka,

2. Singkron Virtual (virtual synchronous), yakni pembelajaran secara langsung namun dalam bentuk virtual,

3. Asinkron Mandiri (sel-paced asynchronous), yakni pembelajaran yang dapat diakses dari manapun dan kapanpun,

4. Asinkron Kolaboratif (collaborative asynchronous), yakni pembelajaran yang dilakukan dari manapun dan kapanpun namun dengan melibatkan orang lain.

Berangkat dari paparan Chaeruman dan Mudiarti sebagaimana dikutip Hamidi, MA Miftahul Ulum mengalami perubahan pola pembelajaran dari yang semula dilaksanakan secara sinkron langsung menjadi sinkron virtual, asinkron mandiri, maupun asinkron kolaboratif, tergantung bagaimana guru mendesain

${ }^{27}$ Ali Sadikin and Afreni Hamidah, "Pembelajaran Daring Di Tengah Wabah Covid19," Biodik: Jurnal Ilmiah Pendidikan Biologi, 6 (2), (2020), 109.

${ }^{28}$ Hamidi, "Strategi Lembaga Pendidikan Islam Dalam Menghadapi Era New Normal Pasca Pendemi Covid-19", 147-148. 
penyampaian pelajarannya selama pembelajaran daring berlangsung. Impelemntasi model pembelajaran blended learning, sebagaimana disebutkan adalah: ${ }^{29}$

1. Proses pembelajaran lebih efektif dan efisian dari segi ruang maupun waktu,

2. Dapat menjadi media belajar baru, sehingga dapat membangun suasana baru agar peserta didik lebih ceria dan tidak mudah bosan.

3. Secara ekonomis lebih hemat karena tidak perlu biaya ekstra untuk mengikuti proses pembelajaran sebagaimana pembelajaran tatap muka.

Permasalahan yang timbul dari penerapan metode pembelajaran jarak jauh ini merupakan sesuatu yang wajar. Sebagaimana diungkap Rowles \&Brown (2017), bahwa teknologi tidak hanya membawa perubahan radikal, namun juga akan terus berubah. Semua lapisan sosial harus memiliki kapabilitas untuk mengimbangi perubahan tersebut. Situasi sekarang ini ialah dimana perubahan teknologi secara radikal yang dikombinasikan secara alamiah dengan pandemic covid 19 membawa perubahan yang lebih dari radikal. 30

Tantangan yang dihadapi tidak hanya di sekolah menengah atas seperti di MA Miftahul Ulum, hasil penelitian juga melaporkan bahwa tidak sedikit mahasiwa yang kesulitan dalam memahami materi perkuliahan yang diberikan secara daring. Bahan ajar biasa disampaikan dalam bentuk bacaan yang tidak mudah dipahami secara menyeluruh oleh mahasiswa.

\footnotetext{
${ }^{29}$ Hamidi, 151.

${ }^{30}$ Stevany Afrizal et al., "Perubahan Sosial Pada Budaya Digital Dalam Pendidikan Karakter Anak," Prosiding Seminar Nasional Pendidikan FKIP Universitas Sultan Ageng Tirtayasa, 3 (1), (2020), 432.
}

Mereka berasumsi bahwa materi dan tugas tidak cukup karena perlu penjelasan secara langsung oleh dosen. Garrison \& Cleveland-Innes melaporkan bahwa kelas yang dosennya sering masuk dan memberikan penjelasan memberikan pembelajaran lebih baik dibandingkan kelas yang dosennya jarang masuk kelas dan memberikan penjelasan. ${ }^{31}$

Dari pemaparan diatas, secara sosiologis keadaan itu disebut sebagai culture shock yaitu goncangan kebudayaan yang disebabkan perubahan lingkungan akibat pandemi covid-19 yang terjadi di masyarakat. Untuk sekarang ini kegiatan pendidikan secara online, yang dulunya selalu tatap muka di sekolah namun sekarang bisa dilaksanakan kelas digital atau bisa juga blended learning setelah pandemi berakhir. Selanjutnya, William F. Ogburn (1992:377) menjelaskan perihal perubahan sosial masyarakat yaitu teori ketertinggalan budaya (cultural lag/social lag). Teori ini mengungkapkan bahwa berkembang cepatnya salah satu unsur kebudayaan tidak sebanding dengan unsur kebudayaan lain sehingga mengakibatkan ketertinggalan unsur dari kebudayaan lain. ${ }^{32}$

Sebagai pembanding dalam hal pelaksanaan pembelajaran melalui media online, hasil penelitian Fitria Novita Sarie menunjukkan bahwa hasil evaluasi pembelajaran melalui WA selama setengah semester, pembelajaran daring melalui WA dianggap menjenuhkan oleh peserta didik karena tidak di dukung oleh fiturfitur yang lengkap. Peserta didik

\footnotetext{
${ }^{31}$ Sadikin and Hamidah, "Pembelajaran Daring Di Tengah Wabah Covid-19", 113.

${ }^{32}$ Afrizal et al., "Perubahan Sosial Pada Budaya Digital Dalam Pendidikan Karakter Anak", 431.
} 
kurang bersemangat karena mereka hanya sebatas dapat membaca pesan dan menggunakan voice note, diskusi antar teman juga terasa kurang optimal akibatnya hanya beberapa peserta didik saja yang aktif saat pembelajaran daring berlangsung. Penelitian Dewi (2020) menunjukkan bahwa adanya pendemi covid-19 sangat berdampak pada implementasi pembelajaran daring di sekolah. Kurangnya fasilitas handphone dan kuota internet menjadi salah satu penyebab terhambatnya pembelajaran secara online. Hasil penelitian Sari (2019) menjelaskan bahwa Penggunaan E-Learning Berbasis Edmodo terbukti efektif dalam meningkatkan Kemampuan Komunikasi Matematika. Kedua penelitian tersebut yang mendasari peneliti untuk memilih Edmodo dalam pembelajaran daring di Sekolah Dasar. ${ }^{33}$

Dari berbagai sudut pandang yang penulis paparkan, baik secara sosiologis, psikologis, maupun filosofis pendidikan, perubahan sosio-kultur madrasah selama pandemi covid-19 meskipun menimbulkan shock culture yang sangat signifikan, di sisi lain memiliki nilai positif, yakni pertama, dalam segi pemanfaatan teknologi dalam proses pembelajaran, dalam artian penerapan kurikulum berbasis teknologi digital dapat dikatakan sudah terlihat konsepnya, mungkin belum maksimal, namun masih banyak waktu untuk disempurnakan. Kedua, paradigma baru tentang sekolah yang tidak lagi terikat dengan ruang kelas, melalui PJJ selama pandemi kita mendapatkan paradigma baru bahwa kegiatan belajar mengajar tidak hanya

${ }^{33}$ Fitria Novita Sarie, "Optimalisasi Pembelajaran Daring Masa Pandemi Covid-19 Melalui Aplikasi Edmodo Bagi Peserta Didik Sekolah Dasar," Jurnal Pendidikan Dasar : Jurnal Tunas Nusantara, 2 (2), (2020), 249. terbatas dalam ruang sekolah, namun dapat dikembangkan dalam media yang lain seperti media sosial dan sebagainya. Pendidikan menjadi lebih dinamis diselenggarakan, belajar menjadi lebih mudah diakses ketika siswa berhalangan hadir di ruang kelas.

Dalam perspektif social engineering, segala macam perubahan yang tejadi secara mendadak selama pandemi covid-19, dapat dijadikan pijakan untuk mendesain sebuah konsep baru kegiatan belajar mengajar madrasah berbasis teknologi digital. Hal ini tentu dapat merekayasa (engineering) sosio-kultur madrasah dengan konsep baru kelak ketika situasi dan kondisi kembali normal dan kegiatan madrasah kembali seperti sedia kala.

Dalam pengembangan dan penerapannya, teknologi banyak aspek dapat diusulkan untuk dijadikan alasan mendukung untuk pendidikan dalam kaitannya dengan peningkatan kualitas pendidikan nasional Indonesia.Teknologi sangat mampu dan diperjuangkan untuk menjadi fasilitator utama untuk meratakan pendidikan dinusantara, karena teknologi yang mengandalkan kemampuan belajar jarak jauh tidak lepas dari ruang, jarak dan waktu.Demi mencapai daerah-daerah yang sulit, aplikasi ini diharapkan dapat dilakukan sesegera mungkin di Indonesia. ${ }^{34}$

Penggunaan platform online seperti Google Classroom, Zoom, lingkungan belajar virtual dan media sosial serta berbagai forum kelompok seperti Telegram, Messenger, WhatsApp, dan WeChat dapat dieksplorasi lebih jauh bahkan setelah

${ }^{34}$ Mar'ah, Rusilowati, and Sumarni, "Perubahan Proses Pembelajaran Daring Pada Siswa Sekolah Dasar", 2. 
pengajaran tatap muka dilanjutkan, dan platform ini dapat memberikan sumber daya tambahan dan pembinaan kepada pelajar. ${ }^{35}$

Sebagaimana dikatakan oleh Gerhad Fortwengel guru besar University of Applied Science and Arts, Hannover, Germany and Senior Experten Services (SES) Germany, bahwa pandemi Covid-19 menjadi katalis hebat yang memacu dunia pendidikan. Sebab mendorong lebih banyak pemanfaatan teknologi informasi dalam aktivitas pembelajaran jarak jauh (daring). ${ }^{36}$

Lebih jauh lagi, meskipun harus diperhitungkan bahwa kurangnya fasilitas teknis dapat menjadi penghalang, penekanannya tidak hanya pada dukungan perangkat teknologinya saja tetapi pada dukungan teknis untuk pengembangan sumber daya manusianya dalam mengimplementasikan teknologi secara khusus dalam proses pembelajaran. ${ }^{37}$

\section{CONCLUSION}

Perubahan sosio-kultur yang terjadi di MA Miftahul Ulum Banyuputih Kidul Jatiroto Lumajang selama pandemi covid-19 mencakup berbagai aspek pendidikan, baik dalam segi kegiatan belajar mengajarnya dari luring menjadi daring, pola komunikasi antara guru dan siswa dari komunikasi langsung tatap muka menjadi komunikasi secara virtual, termasuk aspek psikis guru dan siswa dalam menghadapi kegiatan belajar mengajar.

Perubahan sosio kultur di MA Miftahul Ulum Banyuputih Kidul

\footnotetext{
${ }^{35}$ Pokhrel and Chhetri, "A Literature Review on Impact of COVID-19 Pandemic on Teaching and Learning", 138.

${ }^{36}$ Dzaljad, "Transformasi Sosial Dalam Proses Pendidikan Di Masa Pandemi Covid-19", 308.
}

Jatiroto Lumajang dalam perspektif social engineering dapat dijadikan pijakan dalam mendesain sosio kultur madrasah di masa depan ketika situasi kondisi sudah kembali normal seperti sedia kala, pemanfaatn teknologi digital selama PJJ dapat dijadikan alternatif solusi dalam menunjang $\mathrm{KBM}$, dengan ini tentu ada desain paradigma baru bagi guru dan siswa dalam melihat KBM, bahwa belajar tidak lagi dibatasi oleh ruang dan waktu, sebab pandemi memberi pelajaran berharga bahwa belajar selain di ruang kelas juga dapat dilaksanakan di ruang-ruang alternatif seperti website, aplikasi, bahkan media sosial.

\section{ACKNOWLEDGMENT}

Ucapan terima kasih penulis sampaikan kepada

\section{REFERENCES}

Afrizal, Stevany, Septi Kuntari, Rizki Setiawan, and Wika Hardika Legiani. "Perubahan Sosial Pada Budaya Digital Dalam Pendidikan Karakter Anak." Prosiding Seminar Nasional Pendidikan FKIP Universitas Sultan Ageng Tirtayasa. 3 (1). 2020.

Aji, Rizqon Halal Syah. "Dampak Covid19 Pada Pendidikan Di Indonesia: Sekolah, Keterampilan, Dan Proses Pembelajaran." SALAM: Jurnal Sosial Dan Budaya Syar-i. 7 (5). 2020.

Annisa Mega, N, Dwi Kurnianing Ratri, Agus Timan, Ghasa Faraasya, and Ahmad Khoirul R F. "Perubahan Kurikulum Yang Didasari Oleh Perubahan Sosial Dan Budaya Di

\footnotetext{
${ }^{37}$ Astrid van Twillert et al., "Teachers' Beliefs to Integrate Web 2.0 Technology in Their Pedagogy and Their Influence on Attitude, Perceived Norms, and Perceived Behavior Control," International Journal of Educational Research Open, 1 (1), (November, 2020), 11.
} 
Masyarakat." Seminar Nasional Jurusan Administrasi Pendidikan FIP Universitas Negeri Malang. 2020.

Dzaljad, Rifma Ghulam. "Transformasi Sosial Dalam Proses Pendidikan Di Masa Pandemi Covid-19." Maarif Institute. 15 (2). 2020.

Fauzi, Imron. Etika Profesi Keguruan. IAIN Jember Press. II. Jember: IAIN Jember Press, 2019.

Hamidi. "Strategi Lembaga Pendidikan Islam Dalam Menghadapi Era New Normal Pasca Pendemi Covid-19." Al-Fikrah. 2 (2). 2020.

Indraddin, and Irwan. Strategi Dan Perubahan Sosial. Sosiologi. 1st ed. Yogyakarta: Deepublish, 2016.

Kulsum, Dewi Umi. "Optimalisasi Penggunaan Buku Teks Dalam Upaya Meningkatkan Prestasi Belajar Di SMP." Jurnal Manajemen Pendidikan. 10 (1). 2015.

Maguire, Amy, and Donna McNamara. "Human Rights and the PostPandemic Return to Classroom Education in Australia." Alternative Law Journal. 45 (3). 2020.

Mar'ah, Nur Khairiyah, Ani. Rusilowati, and Woro Sumarni. "Perubahan Proses Pembelajaran Daring Pada Siswa Sekolah Dasar." Prosiding Seminar Nasional Pascasarjana UNNES. 2020.

Moleong, Lexy J. “Metodologi Penelitian Kualitatif." Bandung: Remaja Rosdakarya, 2010.

Patricia Aguilera-Hermida, A. "College Students' Use and Acceptance of Emergency Online Learning Due to COVID-19." International Journal of Educational Research Open. 1 (1). September 2020.

Pokhrel, Sumitra, and Roshan Chhetri. "A Literature Review on Impact of COVID-19 Pandemic on Teaching and Learning." Higher Education for the Future. 8 (1). 2021.
Pradoko, A.M. Susilo. Paradigma Metode Penelitian Kualitatif. Yogyakarta: UNY Press. Yogyakarta: UNY Press, 2017.

Putri, Ayusi Perdana, Rennita Setya Rahhayu, Suswandari Meidawati, and Prapti Agustin Rahayu Ningsih. "Strategi Pembelajaran Melalui Daring Dan Luring Selama Pandemi Covid-19 Di SD Negeri Sugihan 03 Bendosari." Prima Magistra: Jurnal Ilmiah Kependidikan. 2 (1). 2021.

Rigianti, Henry Aditia. "Kendala Pembelajaran Dring Guru Sekolah Dasar Di Kabupaten Banjarnegara." Elementary School. 2 (1). 2020.

Sadikin, Ali, and Afreni Hamidah. "Pembelajaran Daring Di Tengah Wabah Covid-19." Biodik: Jurnal Ilmiah Pendidikan Biologi. 6 (2). 2020.

Sarie, Fitria Novita. "Optimalisasi Pembelajaran Daring Masa Pandemi Covid-19 Melalui Aplikasi Edmodo Bagi Peserta Didik Sekolah Dasar." Jurnal Pendidikan Dasar: Jurnal Tunas Nusantara. 2 (2). 2020.

Schwartzman, Roy. "Performing PandemicPedagogy",Communicati on Education. 69 (4). 2020.

Shalihah, Fithriatus. Sosiologi Hukum. 1st ed. Depok: PT RajaGrafindo Persada Jakarta, 2017.

Sugiyono. "Metode Penelitian Kuantitatif Kualitatif Dan R\&D." Bandung Alfabeta. Bandung: Alfabeta, 2010.

"Surat Edaran Sekretaris Jenderal Kementrian Pendidikan Dan Kebudayaan Nomor 15 Tahun 2020".

Tirka, Wayan, and Ni Made Kusumawati. "Optimalisasi Model Pembelajaran Berbasis Masalah Dengan Berbantuan Lembar Kerja 
Siswa (Lks) Untuk Meningkatkan Aktivitas Dan Hasil Belajar Dalam Mata Pelajaran Matematika." International Journal of Elementary Education. 1 (3). 2017.

Twillert, Astrid van, Karel Kreijns, Marjan Vermeulen, and Arnoud Evers. 'Teachers' Beliefs to Integrate Web 2.0 Technology in Their Pedagogy and Their Influence on Attitude, Perceived Norms, and Perceived Behavior Control." International Journal of Educational Research Open. 1 (1). November 2020.

Wulandari, Taat. "Rekayasa Sosial Kolaborasi Pendidikan Karakter Dan Pendidikan Multikultural: Praksis Di Yayasan Perguruan Sultan Iskandar Muda." Jurnal Pembangunan Pendidikan: Fondasi Dan Aplikasi. 4 (2). 2017.

Zaitun. Sosiologi Pendidikan: Analisis Komprehensif Aspek Pendidikan Dan Proses Sosial. Sosiologi Pendidikan. 1st ed. Pekanbaru: Kreasi Edukasi, 2015.

Zuriah, Nurul, and Hari Sunaryo. "Rekayasa Sosial Model Pendidikan Karakter Berbasis Nilai Kearifan Lokal Dan Civic Virtue Di Perguruan Tinggi." Sosiohumanika: Jurnal Pendidikan Sains Sosial Dan Kemanusiaan. 11 (2). 2018. 